\title{
Enhance Education Child to Build Habit and Character
}

\author{
Rita Nofianti ${ }^{1}$, Rika Widya ${ }^{2}$, Salma Rozana $^{3}$, Munisa $^{4}$ \\ ${ }^{1,2,3,4}$ Lecturer Of Faculty Islam and Humanity, Universitas Pembangunan Panca Budi Medan, North Sumatera, \\ Indonesia
}

Corresponding Author: Rita Nofianti

\begin{abstract}
The risks involved in confronting the challenges of globalization are very high. Today, children's knowledge of the world without equality is not a luxury but one obligation. Improving the professionalism of teaching faculty and caregivers involved in early childhood education is extremely important because early childhood is a critical year for children's development and hence their readiness to trace the realm of formal schooling and adult life. This paper described As recognized through studies; early childhood education impacts their overall development, whether physical, social, emotional, and intellectual, influenced by the quality of Kindergarten programs presented and teachers educating through the curriculum offered and the teacher's competence.
\end{abstract}

Keywords: development, education, change habit.

\section{INTRODUCTION}

Program quality is emphasized (not just program offerings) because of impact on early childhood development (Rohaty 2009); The impression of early childhood education is proven through programs that are neatly designed and then give a shortterm impression as well as a long-term impression on children's development (Weikart). Other aspects of social impact. Such as increased mental health, reduced poverty gap, high community welfare, shortages of crime, and lack of retention in schooling. Quality experience impacts academic and social success, and naturally, programs that all families can enjoy become an important social agenda in a country.

Resurfacing in the Early Childhood Education program, high quality is carried out because of the strong economic return, namely adding the income power of parents, so that parents can work while their children are served and educated in Playgroup and Taska. The positive impression of ECCE (Early Childhood Care and Education) is seen as an antidote to provide opportunities for high-risk children to make adaptations to school and maximize their efforts at an earlier stage in life (Rohaty 2009). In Malaysia, the Education Development Plan (2015-2025) supports the philosophy of realizing equality and equal educational opportunity regardless of ethnicity, gender, and socioeconomic status. The philosophies supported are No Child is Left Behind, and The Child is the Jewel of the Nation.

To get the impression of a good extension for the community and the state, the quality of professionalism of lecturers and teachers is mandatory at every level because they are the ones who make an educational program successful. Playgroup teacher education programs must be designed so consciously and neatly given the turbulence of the 21st-century environment, providing input and feedback to the university program itself. Current and futuristic demands also influence the style of college training that needs to change to continue to advance and be relevant for future child development. Educators and 
caregivers are facilitators of teaching and learning.

The 21st century or globalization strategy for early childhood teachers has been widely discussed. Globalization refers to the realization of relations between nations and between people worldwide through various means, including communication, transfer interactions, and travel. Competition in the global world is very competitive so that high-quality human resources are needed. Globalization has resulted in creating a borderless world without geographical, economic, social, and cultural boundaries. The invention of the internet, the early telephone, and satellite television accelerated global communication and experience and the explosion of information all the time.

Efforts to ensure that children develop to meet the demands of the era globalization has been identified such as the importance of skills in using technology, development of thinking skills (HOTS) such as creative and critical thinking, problemsolving and collaboration, awareness of the global world and the world around it, and social responsibility to ensure the world occupied is safe, peaceful and avoidable and not undermining humanity and justice.

Claims the era of globalization requires an understanding of the diversity (diversity) of multi-culturalism (various cultures), achievement and fluency in various languages between nations, environmental safety, and survival skills. In essence, providing children for a borderless village or world is the duty and responsibility of universities, colleges, teacher training programs, and families. The main problem is how to provide qualified lecturers and prospective teachers to face the demands of globalization. Early childhood educators should not sit in a glass shell where the light can only see out but cannot get out of the glass box.

What to plant in a college training program at a university and colleges to equip teachers to be efficient in facing the demands of the globalization era. Are educators who are said to be qualified 21 stcentury resources in this informative era? Traditionally and usually, college training contains core components such as philosophy, curriculum, pedagogy, and assessment, so these components need to be studied for solid filling. The organizers of the Educational Training program must share common values and get an agreement on how to improve the quality of teachers and lecturers. This is the task and commitment to administering universities and academic programs at the faculty. The strategy adopted needs to cross the curriculum that provides input to produce authoritative global lecturers and educators.

The process of ensuring the quality of early childhood teachers requires that the organizers of the College Training program examine several components related to the education component including (a) philosophy and matlamat; (b) Program Objectives; (c) Curriculum design; (d) Pedagogy and Practicum; (e) Assessment; and (f) Source Support.Meanwhile, there are various factors that also affect the quality as shown in the diagram below. The modifiers include (a) the philosophy and objectives of the program; (b) Teaching and Learning; (c) Code of Practice (Code of Practice); (d) Measurement and Assessment of the program; (e) Recruitment quality for Playgroup's teachers; (f) Resos and human resources; and (g) Improvement (CQI) (Continuous quality improvement).

The program's philosophy naturally aims to produce knowledgeable, skilled lecturers and have a positive attitude to guide children who grow up in the era of globalization and the era of information. The characteristics and characteristics of the 21 st-century globalization era are very important to be refined to foster the goals of the College Training program. Children no longer live limited to their geographical area but now cross the global village border and are no longer focused on knowing one country but various countries on the world map. The Philosophy of the College Training Program produces graduates who 
are knowledgeable in child development and gives birth to graduates who are multitasking and creative.

\section{LITERATURE REVIEW}

The program's INFORMATION and objectives are stated in the (PLO) Objective Learning Program. This is always referred to in the Code of Practice Quality Assurance document. Program Learning Outcomes and Learning Outcomes Courses should support the elements and ingredients of early childhood education professionalism and apply early childhood interests. It can be formulated that teachers and lecturers should be appropriate, have extensive and intensive knowledge about how children learn and develop, know about various early childhood programs that exist on the local and global stage (global and local), and have excellent knowledge and skills for education - early childhood.

\subsection{Strategies Educational Training} Programs (Program Learning outcomes)

Compulsory learning outcomes include three aspects, namely:
(a) Skills;
(b) Attitude; and
(c) Knowledge

Those skills are not exhaustive, and they may increase from time to time as required. Proficiency refers to the actions teachers take in teaching and learning. After graduating from the Early Childhood Education Program, the appropriate graduates are:

- may design, implement and assess developmentally appropriate curriculum (DAP)

- can apply technology and be creative and create software related to teaching

- can solve the problem

- can resolve internal and external conflicts

- maybe affectionate and show identification with children

- can connect with the community and parents
- can carry out an easy action study

- may discipline children and modify behavior

- may reflect on his teaching and daily incidents

- can show high-quality work

- can lead and take care of the tradition perfectly

- can show a willingness to learn for life

- can integrate children from various backgrounds

- can respect parents and community

- may assess a child's progress using various methods

- can analyze educational and social issues between nations

- can speak in second and third languages

- can communicate through active listening

- using various conquests (reasoning) (inductive and deductive)

- can adapt to the changing era of ICT

- can make synthesis and analysis

- can interpret information

- may use coaching techniques and idea mapping

- may adopt the teaching according to the climate in the Playgroup room

- can carry out self-directed projects

- Can carry out various teacher roles (multiple roles)

- can work together as a team

\subsection{Proficiency in Various Teaching Methods}

Lecturers also need proficiency in various styles and approaches to teaching because of the differences in the background of the children being educated. This difference is obvious because new phenomena have emerged, such as children from the SES group, runaways, children from non-intact families, children without democracy or citizenship, and children falling into wars and conflicts. Their experience is somewhat different. Teachers need experts to assess their temperaments and needs through active interaction in the Playgroup room, and teachers need to show 
empathy with them. Children also differ in terms of their level of intelligence, interest, and motivation. In inclusive education, it is natural for teachers to understand the character of every child.

Awareness about a world without borders and the existence of countries with different cultures outside the borders of one's own country must be sown. In essence, in an atmosphere of teaching and learning, lecturers need to be knowledgeable about the world and the upheavals that occur through reading studies and linkage between nations.

\section{MATERIALS \& METHODS}

Pedagogy in playgroup, it is customary to combine subjects or disciplines taught across pure values and touch the total development of children. Teachers need to review world problems or social developments outside the country that are interesting and need an interesting approach. The project approach, the problem-solving approach, the inquiry approach provides lecturers and teachers with a deep interest in the world in Gaza, Palestine, Biafra, London, Tokyo, and Cairo. Through such an approach also children; Children are raised to live highlevel thinking (HOTS), and the teacher is naturally as a group who practice high-level thinking.

\section{(a) Attitude and Disposition}

A brilliant educator has a positive attitude and becomes a model and motivator to the people around him, whether they are children or other adults, including parents. It is futuristic, has a clear vision and mission, and is forward-looking.

$\mathrm{He}$ is innovative and creative, and open-minded. He is willing to try out new ideas and review study findings, and use them in teaching. He is happy to share his experiences in the community of learners.

He has the great internal motivation and likes to be side by side with child naturally and naturally; He always wants to improve himself by seeking new knowledge and reading the results of studies to expand his mind. $\mathrm{He}$ is responsible for his profession and likes to be among expert professional icons.

\section{(b) Knowledge presented through curriculum design}

Program design is closely related to the Program Objectives because this is where all the courses that are presented for prospective lecturers and teachers are placed; The reasonable curriculum developer integrates not only basic educational courses such as sociology, philosophy, psychology, and curriculum but also trending courses that meet the demands of the 21st century including 21st-century courses such as the Global Awareness Course; Diversity Courses and Multicultural Courses Environmental awareness courses; Counselling courses and Bilingualism courses important for the 21st century; So is the Technology Integration course in pedagogy. Training and skills in integrated technology.

Technology and ICT are important because children born in this century (alpha gene) are involved with the iPad, the internet Facebook; some are more proficient than their parents, and their teachers use them. Teachers need to be more expert than the child's appropriateness to be able to provide effective guidance and become a mentor to the child. Not only do teachers need to understand technical skills, but they also need to be creative in enlivening the learning atmosphere by integrating ICT. Not only to develop teaching designs but also to become producers of products. Program design needs to focus more on authentic approaches, play based and project based approaches and inquiry approaches.

Courses need to emphasize sensitivity to culture, linguistics and cultural heritage values; Other courses include impressive Communication Skills: Electronic portfolio development. All courses need to be DAP (developmental) (Bredekamp 1992); It is mandatory to carry out an International Language Skills course 
because of the need for a world language that allows higher competitiveness. Several issues that also need to be refined are integrating field experience supervised by foreign lecturers to optimize global experience.

It can be formulated that $21 \mathrm{st}$ century skills include components of critical thinking, innovation, communication and collaboration, scientific literacy and numerical literacy, information literacy, ICT literacy, global awareness, entrepreneurial literacy, civic literacy and environmental literacy. Nor is his work skills, crosscultural skills, leadership and productivity reduced. Lecturers of universities and colleges should naturally have the ability to have these knowledges to form future Playgroup/Taska teachers.

\section{The need to have knowledge about child development}

As educators and caregivers if he is natural and obliged to study the science of child development and how they learn. There are twelve important principles of child development as suggested by (NAEYC):

- All developmental domains are important

- Learning and development follow a certain order

- Learning takes place at different rates

- Applicable learning is the result of the interaction of maturity and experience

- Early experience has an important impression on the development

- Progress goes from concrete to symbolic

- Children develop well if they have a safe relationship and safe.

- Development influenced by different social and cultural contexts

- children learn in different ways

- Game It is important to develop selfdirection and to develop language and cognition

- Children learn through challenges in learning
- Children's experiences build their motivation and learning approach

\section{(c) Assessment Strategy for Teaching}

Lecturers and teachers in globalization need to be knowledgeable and skilled in carrying out assessments for quality programs and children's achievements. Lecturers need to be trained to carry out various types of assessments, whether quantitative or qualitative, formative and summative assessments. Teachers need to monitor children's learning in a world where the explosion of knowledge is mounting every day. Teachers need to measure the same child who believes in learning, and the teacher deserves solid support.

The rubric to support reasonable learning outcomes shows how many semester hours are allocated for courses in childhood developmental theory, child diversity, and internships with multicultural children. In one semester, how many credit hours are allocated for studying foreign languages and technology and other educational aspirations courses such as sociology, technology, philosophy. How many hours are devoted to teaching methods and action studies? Fair curriculum design symbolizes a strong interdisciplinary curriculum (interdisciplinary), whether the curriculum is outmoded or outdated.

\section{(d) Teacher Entry Strategy}

The quality of lecturers and teachers is related to input, especially graduation and the experience of candidates occupying the Teacher Training Program. In Malaysia, it is expected that all can get a baccalaureate to become a preschool teacher, but for a diploma, it is only necessary to have a few credits after the SPM examination only. In addition, it is necessary to have a personality test designed to measure the personality and commitment, and interest of teachers. Because it requires teachers who have many numbers, leeway attracts prospective teachers who have too low a pass; this will affect the quality of the 
graduates. So it is necessary to ensure that candidates who have good academic graduation are accepted.

\section{RESULT}

As a reference, the Faculty and College Training Programs need to have sufficient reference sources, including journals that are up to date and reflect field expertise. Lecturers and students must be provided with textbooks, materialsaudio and digital are sufficient to satisfy the mind's diet. Referral resource centers need to exist not only in the physical poles but also online and virtual. Lecturers need to increase their knowledge through study reports in the field of early childhood education to reflect and bring about changes in their expertise.

The strategy of implementing continuous improvement must ensure excellence in the quality of programs and teachers. Programs and faculties need to deal with changes and explosions of new knowledge; need to compete with a world without borders; Therefore, the curriculum should not be orthodox and static. reviewed at least every 4 years; The recommended mechanism is to appoint an external appraiser; the pious; Linkage or relations with industry need to be carried out to review market needs; Dialogue with stakeholders or those who hold interests and interests is highly treed. Do not miss the involvement of staff in the conference as invited speakers and forum experts. National (national) and inter-national approach strategies are encouraged to be limited to regional ones.

Smart sharing is important for living up to shared value systems and so that there is a comparison of achievements between the Playgroup and Taska types and their philosophies. If there is an agreement about the core and the principle of Quality or the concept of the teacherquality, discrimination will not apply. Reflective educators canprovide professional judgment and professional input; The quality of the training programthe teacher focuses on clear objectives, program evaluations from time to time and reports the results of the assessment to clients and interested parties (stakeholders) Continuous improvement emphasizes the collaboration between professional union education leaders, the business community and basic stakeholders. There is a need for benchmarking on Quality Assurance at international rankings.

To their professional development process. This includes the stages they have gone through since becoming novices to teachers who are experts in the field of early childhood education (Sheridan 2009). How do educators in Playgroup acquire new knowledge and skills? What are the factors or modifiers that affect the attainment of skills and knowledge? What are the motivations and behaviors of coaches and mentors that are effective and advance the educators being mentored? What are the qualities of a good consultant?

To guide teachers in solving problems? Why is someone more willing to learn for life? Is a more effective training approach either in training or pre-training? What sustains educator motivation? What support can be obtained to make a professional training program a success? What is the relationship between practice and learning success at Playgroup.

\section{CONCLUSION}

Everywhere there is an attempt to implement a change such a great challenge. This change is especially painful for those who are already so happy and attuned to the existing mental scene. The following diagram shows the barriers to change that include a variety of commonly encountered factors. Achieving new goals is not easy and sometimes neglected. Reluctance to change is due to fear that new changes will take time and be difficult. Humans have various motives and interests of their own, including the values they promote. Sometimes the change is considered too big and they are reluctant to implement it, for example, if you focus too much on the quality of prospective teachers, no candidate may agree to apply for the position. 
The quality of lecturers and future teachers depends on various components that influence each other. This component is often mentioned in the Quality Assurance document that is put forward for the accreditation of the PAK (early childhood education) program in all countries. The quality of lecturers in the era of globalization requires him to also become a global player with certain characteristics. The quality of college training for early childhood depends on the input (experts, curriculum, resources, finances), the process (the actual training mechanism of the program), program assessment and output assessment (See graduate quality) can be obtained through (trace studies or trace studies) Training programs colleges in Early Childhood Education need a pedagogical reference framework that translates curriculum theory into practice; The quality of the program is improved through professional.

\section{Acknowledgement: None}

\section{Conflict of Interest: None}

\section{Source of Funding: None}

\section{REFERENCES}

1. Burchinal, Margaret R.; Cryer, Debby; Clifford, Richard M.; \& Howes, Carollee. Caregiver training and classroom quality in child care centers. Applied Developmental Science, 6(1), 2-11. 2002.

2. Buysse, Virginia, \& Wesley, Patricia W. (Eds.). Evidence-based practice in the early childhood field. Washington, DC: Zero to Three. 2006.

3. Bamber, V., Trowler, P., \& Saunders, M. (Eds). Enhancing learning, teaching, assessment and curriculum in higher education: theory, cases, practices. Maindenhead, UK: Open University Press. 2009.

4. Bredekamp, S. (Ed.). Developmentally Appropriate Practice in Early Childhood Programs Serving Children from Birth, through Age 8. Washington, DC: National Association for the Education of Young Children, 1987.

5. Kathyn Tout et al., The Child Care Quality Rating System (QRS) Assessment: Compendium of Quality Rating Systems and Evaluations, (Washington, DC, 2010), www.acf.hhs.gov/programs/opre/cc/children _quality/compendium_qrs/qrs_compendium _final.pdf(accessed June 11, 2012).

6. Preliminary Report Malaysia Development Plan (2013-2025) Ministry of Education Malaysia, 2012.

7. Rohaty Mohd Majzub, Preschool Education Quality Challenges, SME Publishing, 2009.

8. Rohaty Mohd Majzub, The development of a web based ecological assessment of school readiness (WEBEASR), Procedia - Social and Behavioral Sciences, Vol. 1, No. 1, 2009.

9. Schweinhart, LJ, The Effects of High Scope Perry Preschool study through age 40, High Scope Press: Michigan, 2005.

How to cite this article: Nofianti R, Widya R, Rozana S et.al. Enhance education child to build habit and character. International Journal of Research and Review. 2021; 8(8): 299-305. DOI: https://doi.org/10.52403/ijrr.20210841 